\title{
Implementing Communicative Language Teaching Approach at Innovative Learning Center Sidoarjo
}

\author{
Sulistyaningsih \\ STKIP PGRI Sidoarjo, email: sulistyaningsih3112@gmail.com
}

Dina Astriana

STKIP PGRI Sidoarjo, email: dinaastriana@gmail.com

\begin{abstract}
:
English language is a universal language which is spoken by most countries throughout the world. Teaching English as a Foreign Language (EFL) setting is challenging for teachers. They have to share the English knowledge based on the curriculum and be creative in developing activities in the class. One of the the approaches taught to learners is Communicative Language teaching(CLT) approach.. This study aimed to collect the information on teacher's comprehension of Communicative Approach and describe the implementation of Communicative Approach conducted by the teachers. The subject of this study was five English teachers at Innovative Learning Center, Sidoarjo. The observer collected the data from questionnaires, interview and observation. The findings showed that 4 teachers (80\%) understood about the communicative language teaching approach and all of them (100\%) have conducted the communicative approach in the English teaching process.
\end{abstract}

Key Words: communicative language teachings, implementation, communicative approach

\section{INTRODUCTION}

Learners of English as a foreign language learn four language skills which are speaking, writing, listening and reading skill. More over, they also have to master two language components: vocabulary and grammar. In my experience, teaching English as a foreign language was challenging. The teachers needed to be innovative, creative and to implement the interesting approach so the students felt at ease when they learnt English. The objective of this study was to collect information on teacher's understanding of communicative approach and how the teachers ed the communicative approach principles by applying communicative activities in teaching English. Many students felt nervous and shy to practice English or expressed ideas because they were afraid to make mistakes. They found difficulty in learning English because the learning atmosphere was so formal. The teachers needed to implement fun and interesting activities in the learning process so the students could have high motivation to learn English and enjoy it. Motivation is important for the students to improve the language skill. Motivation is intended to grow willingness of the students to speak or practice English 
(Ryan 120). Motivation is some kind of internal drive to encourage somebody to persuade a course of action (Larsen-Freeman 45). The goal of the English learning could be obtained when the students could maintain good motivation, interact actively with their peers and communicate joyfully.

\section{REVIEW OF LITERATURE}

\section{Communicative Language Teaching}

Communicative Language Teaching (CLT), well known as Communicative Approach was a teaching approach that emphasized the interaction as the mean and the goal of language learning. Communicative Language Teaching (CLT) is an approach in teaching language that emphasizes authentic communication from beginning of class (Horwitz, 2008). Communicative Approach is one of the methods that engage the teachers to be more creative to create activities which support the students to use the language for communication. This approach also has other names, Communicative Language Teaching (CLT) or Functional Approach (Littlewood). According to Communicative Learning Teaching, the language learning goal was the ability to communicate in the target language. The teachers did not mostly focus on grammatical or structure lessons. CLT places the teachers as a facilitator instead of an instructor. More over, CLT used the non-methodical approach that did not use a textbook series to teach the target language, but rather works on improving verbal skills prior to reading and writing. Communicative Language Teaching was a set of principles about the goals of language teaching, how learners learnt a language, the kinds of classroom activities that best facilitate the learning and roles of the teachers and learners in the classroom (Richards, 2006:2). Brown (2001) gave another key important factor related to CLT was less attention to discussion of grammatical rules because CLT attempted learners to use authentic language. This factor showed that teachers would better to apply discussion, dialogue, drill and exercises in teaching and learning process. Sometimes, this was not easy for teachers. Most teachers recognized that grammatical rule was simple, particularly for non native speaker of English teachers (Brown, 2001).

\section{The Principles of Communicative Language Teaching}

In teaching English using communicative approach, there were several major principles (Brumfit 30), such as : (1) Language learning was learning to communicate using the target language; (2) The language used to communicate must be appropriate to the situation, the roles of the speakers, the setting and the register; (3) Communicative activities 
were important. Activities should be conducted in a situation and had a purpose. Typical activities of this approach were: games and role-play; (4) Learners must have constant interaction related to target language; (5) Development of the four macroskills - speaking, listening, reading and writing; (6) The topics were selected and graded regarding age, needs, level, and students' interest; (7) Motivation was the main point. Teachers should encourage students' interest from the beginning of the class activity; (8) The role of the teacher was that of a guide, a facilitator or an instructor; (9) Trial and error was considered part of the learning process; (10) Evaluation concerned not only the learners' accuracy but also their fluency. Communicative Language Teaching uses the real- life situation that creates a realistic context for language acquisition in the classroom (Celce-Murcia 35). The learners must be able to express their own ideas, feelings and needs within the group and the classroom procedures while teaching-learning activities are going on.

\section{Teacher's role as a facilitator}

One of the key points of CLT was promoting the effective use of English for second language learners in social interactions. According to Finocchiaro and Brumfit (1983), in CLT activity, teachers encourage students to communicate with other people in pair and group work (as cited in Brown, 2001, p. 45). Since the teachers' roles were facilitators, the teachers attempted to encourage students to use language communicatively. The learning process emphasized on student-centered method. Taylor (1987) stated that learnerscentered instruction makes students feel secure and free to do exercises in their own initiative in communication. The teachers needed to build good learning atmosphere so the students could enjoy the learning process. Applying fun and interesting yet effective activities was the main concern of a teacher as a facilitator.

\section{Communicative Language Teaching Activities}

There were several interesting activities to create a communicative learning in the classroom:

a. Role-play

Role-play was a communicative activity that motivate students to play a certain role. Students got to interact with their peers. Students were given a certain role to play in a conversation or other kind of interaction. The teachers needed to give students some instructions on what to express or how to do. At last, the students acted out the scenario and the teacher could give feedback and discussed the outcome of the exercise with the students. Ladousse (1987) explained the special reasons to use role play; they are students experiences can be brought into classroom, students can develop their form of 
language, students learn how to interact in several situations, role play help students to minimize self inferior, role play is fun and role play can develop fluency in language.

b. Filling in missing information

Filling in missing information was a fun communicative activity that let the students to practice oral and written expression. Before the lesson, the teacher prepared two sheets per pair of students. Each student asked questions and their partners filled in the missing information. After all the pairs had finished, the teacher could discuss it.

c. Telling a story

This activity was also interesting and fun. The students practiced how to tell stories. The teacher could divide the students in small group. The teachers could use a song and a ball. The activity started as the teachers told the first sentence of the story, played a song and passed the ball onto a student next to them. After several time, the teachers paused the song. The students had to continue creating the story and passing it on again to the next student.

d. Describing a picture

This communicative activity was excellent to practice oral expression. The students sit in pairs and the teacher gave one student of each pair one picture. The student who held the picture had to describe it by giving some clues to his partner. The partner needed to guess what picture it was.

\section{RESEARCH METHOD}

The research was conducted at Innovative Learning Center, Sidoarjo. The participants consisted of five English teachers. The instruments used were interviews, questionnaires, and observations. This was a qualitative study. The research procedure was used to collect the information on the implementation of communicative approach principles used by the teachers in teaching of English at Innovative Learning Center, Sidoarjo. This descriptive study tried to describe the implementation of communicative approach principles (Brumfit 30). More over, it collected the information to find out the teachers' comprehension of the communicative approach principles in teaching English as a foreign language, to know how the teachers implemented the principles in the learning process and evaluated the students learning in implementing communicative approach principles in teaching English at Innovative Learning Center, Sidoarjo. Observation was used to find the information about the implementation of communicative approach principles in the teaching and learning process in the classroom. Questionnaires distributed to the teachers to know teachers' knowledge about communicative 
approach principles. The observation and interview is conducted to assess how the teachers implemented Communicative Approach in the teaching and learning process and the way they give feedback or evaluation.

\section{DATA ANALYSIS AND DISCUSSION}

\section{The Teachers' understanding of Communicative Approach}

The data obtained which was related to the teachers' understanding of Communicative Approach showed at table 1.

Table 1. The teachers' Understanding of Communicative Approach

\begin{tabular}{|l|l|l|l|}
\hline No & \multicolumn{1}{|c|}{ Items } & \multicolumn{1}{|c|}{ Responses } & \multicolumn{1}{|c|}{ Respondents } \\
\hline 1 & $\begin{array}{l}\text { Do you understand the Communicative } \\
\text { language approach? }\end{array}$ & $\begin{array}{l}\text { a. yes } \\
\text { b. no }\end{array}$ & $\begin{array}{l}4(80 \%) \\
1(20 \%)\end{array}$ \\
\hline 2 & $\begin{array}{l}\text { How do you get the information about the } \\
\text { communicative approach principles? }\end{array}$ & $\begin{array}{l}\text { a. In house training } \\
\text { b. internet } \\
\text { c. book } \\
\text { b.Colleague }\end{array}$ & $\begin{array}{l}5(100 \%) \\
4(80 \%) \\
1(20 \%) \\
2(40 \%)\end{array}$ \\
\hline 3 & $\begin{array}{l}\text { Do you implement the communicative } \\
\text { approach principles in the class? }\end{array}$ & $\begin{array}{l}\text { a. yes } \\
\text { b. no }\end{array}$ & $0(100 \%)$ \\
\hline 4 & $\begin{array}{l}\text { Is communicative approach easy to } \\
\text { implement in your class? }\end{array}$ & $\begin{array}{l}\text { a. yes } \\
3(60 \%)\end{array}$ \\
\hline 5 & $\begin{array}{l}\text { Is communicative approach effective } \\
\text { to apply in teaching? }\end{array}$ & $\begin{array}{l}\text { b. no } \\
\text { b. no }\end{array}$ & $\begin{array}{l}5(10 \%) \\
0(0 \%)\end{array}$ \\
\hline
\end{tabular}

Table. 1 shows the information about the teachers' understanding of Communicative Approach principles. There are five questions distributed to all five respondents (English teachers). The data presents that $80 \%$ of them understand the communicative language approach. However, 20\% of the respondents don't understand it. All of them (100\%) get the information about the communicative approach principles from in house training that is held regularly. 4 of them $(80 \%)$ got the information from the internet. The other respondents chose from book (20\%) and from colleagues (40\%). The respondents also got question whether they implement the communicative approach in the class. All respondents (100\%) implemented the communicative approach to the students in learning process. The researcher also obtained the information from the respondents whether communicative approach is easy to implement in the class. 3 respondents (60\%) stated that it is easy to implement it and 2 of them (40\%) stated that communicative approach is not 
easy to implement. To know the information whether Communicative Approach is effective to apply in teaching, the researcher contributed one question for the respondents. All teachers (100\%) stated that Communicative Approach is effective to use in the class. It means that the English teachers at Innovative Learning Center Sidoarjo agree that Communicative Approach is still suitable to use in teaching English.

\section{The Implementation of Communicative Approach}

The researcher observed the implementation of communicative approach conducted by the English teachers at Innovative Learning Center Sidoarjo. The data obtained was divided into pre teaching (preparation), whilst teaching and post teaching. In pre teaching (preparation) process, the researcher collected the data from the teacher's lesson plan and the teaching tools that were prepared. In whilst teaching process, the data collected were about what and how the teachers implemented Communicative approach activity in the teaching process. In post teaching process, The data was taken from the evaluation conducted by the teachers after the learning process.

\section{a. Pre Teaching (Preparation)}

All of the teachers of Innovative Learning Center Sidoarjo (100\%) made the lesson plan. It was one of the procedure of pre teaching activity to prepare the lesson plan, worksheet and teaching aids such as balls, dices, cups. The blank form was available for all of the teachers and they made the standardize lesson plan. The lesson plan consisted of the date, level name, teacher's name, meeting number, main aim, and the activity. It was a must to prepare some communicative language teaching activities. The lesson plan should be checked by the coordinator.

\section{b. Whilst Teaching}

The data related to teaching process indicated that all teachers (100\%) implemented Communicative Approach in teaching English for their students in the classroom. The data showed that all 5 respondents (100\%) gave communicative activities in teaching process, 4 of the respondents $(80 \%)$ often let the students expressed utterances and ideas even though not in good structure, 1 of them (20\%) rarely did it. From the classroom observation, the data showed that all of the teachers $(100 \%)$ did the pre activities: greeting, giving warmer activity and reviewing the material. All of them also conducted communicative activities in the classroom such as mix and mingle, role play, you read I write, fill in the blank, etc. 3 respondents $(60 \%)$ often drill the students certain vocabularies, 2 of them (40\%) rarely did it. The media 
and teaching tools that were used mostly by the teachers were flashcards, dices, playing cards, buttons and balls. All of the teachers (100\%) grouped the students in pair or small group. In order to practice good pronunciation, the data showed that 3 of the teachers $(60 \%)$ often focused on the pronunciation by conducting certain activities: repeat after the teacher, said the word, read aloud. The teachers also taught 4 language skills. All of them (100\%) taught speaking skill dominantly. The other language skills such as writing, reading and listening skills are taught in less portion of time. The data showed speaking skill was the major activity taught by the teachers through some fun and communicative activities. All of the teachers (100\%) used some interesting teaching tools : balls, songs, dices, flashcards to encourage students to speak and mingle with their peers. All of the teachers used the computer or LCD Projector in the classroom especially for listening section. They also often used internet to search Youtube videos. In the teaching process, communicative activities always used. The major activities used by all of the teachers were You read I write, role play, mix and mingle, dice-game, board game and board race and other interesting games. Games was an important part in the teaching process and all of the teachers often conduct new games by using buttons, cups, ice cream sticks, paper clips, etc. Related to the materials presenting in the teaching process, all of the teachers (100\%) used textbook to present the materials and asked the students to do the exercise, discussed it and checked the exercise together in the class. 4 teachers $(80 \%)$ let the students make mistakes and 1 teacher $(20 \%)$ often corrected the mistakes made by the students.

\section{c. Post teaching}

After the teaching process, all of the teachers (100\%) wrote the mistakes made by the students while they were doing activities on the board and discussed the mispronunciation or grammar mistakes. They evaluated the learning process and the mistakes after teaching. The teachers always asked the students about what lesson they had studied before closing the class. After the teaching process finished, the coordinator who regularly observed the teachers gave evaluation and feedback to the teachers regarding the lesson, presentation, communicative activities, body language, pronunciation, time management and class handling. The feedback is needed in order the teachers can improve their teaching skill and knowledge. 


\section{CONCLUSION}

The research findings show that the teachers at Innovative Learning Center Sidoarjo understand about communicative language learning approach. They get regular teaching training from the institution and it improves the teachers's understanding. The understanding of the approach provides useful information to create the teaching and learning activities in the implementation of communicative approach. All of the respondents (100\%) states that Communicative Approach is effective to apply in teaching English in the classroom. The observation result shows the teachers have conducted the implementation of Communicative Approach in teaching English. The teachers are the facilitator that concern about student-centered approach in the class activities during the teaching process and conducted interesting activities such as role play and games. The teachers also give evaluation to the students after the teaching process. All the teachers have developed some activities that refer to Communicative Approach principles. Communicative activities that the teachers often use are: game, mix and mingle, question and answer, role play, debate and information gap. These activities are conducted to build joyful atmosphere in learning process so the students can feel relax and participate actively in learning English.

\section{REFERENCES}

Brown, H. Douglas. "Principles of language teaching and learning." (2000): 277-278.

Brumfit, Christopher. "Applied linguistics and communicative language teaching." Annual Review of Applied Linguistics 8 (1987): 3-13.

Celce-Murcia, Marianne. "Language teaching approaches: An overview." Teaching English as a second or foreign language 2 (2001): 3-10.

Horwitz, E.K. 2008. Becoming a language teacher; practical guide to second language learning and teaching. Boston: Pearson Education.

Ladousse, G.P. 1987. Role play. New York: Oxford University Press.

Larsen-Freeman, D. (2000). Techniques and Principles in Language Teaching (2nd ed.). Oxford: Oxford University Press.

Littlewood, W. T. 2002. Communicative Language Teaching: an Introduction. Cambridge: Cambridge University Press.

Richards, J. C. (2006). Communicative Language Teaching Today. New York: Cambridge University Press. 
Ryan, Stephen. "Self and identity in L2 motivation in Japan: The ideal L2 self and Japanese learners of English." Motivation, language identity and the L2 self (2009): 120-143.

Taylor, B.P. 1987. Teaching ESL; incorporating a communicative, students-centered component. In M.H. Long., \& J.C. Richards (Ed.), Methodology in TESOL (pp. 45 58). Boston: Heinle \& Heinle Publishers. 